\title{
Design of Social Justice In Administrative Courts
}

\author{
Indriati Amarini ${ }^{1 *}$ \\ ${ }^{1}$ Faculty of Law, Universitas Muhammadiyah Purwokerto, Purwokerto, Indonesia
}

\begin{abstract}
This study attempts to discover that an administrative court is a justice institution used as an access by people to get justice in administration. The administrative court carrying out the supervisory function of state administrative action has to be able to give justice in the administration, namely the social justice. The social justice is built on the state's philosophy, Pancasila, namely the balance between the individual rights (individual interest) and the public interest so as to create balance, concordance, conformity, and harmony between the government and the people.
\end{abstract}

\section{Introduction and literature review}

The national development, which is multi-complex, has the effect that the government has a lot of interference in all sectors of people's life. The existence of state administrative obligation in serving the citizens, namely realizing citizen friendly, makes the modern law states use the Administrative Law as the instrument to control the state administration. The use of the Administrative Law is not only as a means of regulating and enforcing, but also as a means of limiting the power of the state itself [1].

In order to provide such protection, a justice institution is needed to provide an access for people to get justice. One of them is the Administrative Court, which provides a justice access for people who seek justice in the field of state administration.

\subsection{Justice Meaning within the Perspective of State Administrative Law}

The existence of the Administrative Court institution becomes crucial in providing a legal protection for individual interest and in enforcing as well as protecting the human rights [2]. Legal protection efforts given by the Administrative Court have to be understood within a balanced framework. It means that the protection for people against government's actions has to be seen within the framework of a greater interest. The government has a main duty to serve the public so that a partial legal protection will be given only if the protection is not contradictory with the interest of legal protection for a larger community. The Administrative Court as a justice institution has to be able to accommodate the aspirations from both parties [3].

The Administrative Court has two functions: First, to enforce the administrative law and second, to control the implementation of government's power in formulating administrative

*Corresponding author: indriatiamarini@ump.ac.id 
regulations or implementing administrative decisions. The existence of the Administrative Court is also to maintain the balance between individual interest and public interest.

The Administrative Court in Indonesia is built on the basis of the state's philosophy, Pancasila, which maintains the balance, concordance, conformity, and harmony between the government and the people. There are four elements of Pancasila Law State, namely (a) a correlation conformity between the government and the people based on the principle of harmony, (b) a proportional functional correlation between the state's power, (c) the principle of resolving a dispute through a discussion and putting the courts as the final solution, and (d) a balance between the rights and obligations [2].

\subsection{Social Justice Design in Administrative Dispute Resolution}

Justice is one of the most important goals of every legal system besides the other legal objectives, namely legal certainty, expediency, and order. In addition to legal objectives, justice also can be seen as a value. There are four values which becomes the important foundations of a good human life, namely justice, truth, law and morals. Justice is the supreme virtue, as stated by Plato: Justice is the supreme virtue which harmonizes all other virtues.

Justice has a various meaning. There are three words, namely qisth, 'adl, and mizan in various forms used by the Holy Al Quran within the context of command to humans to be fair [4]. In the perspective of Javanese culture and ethics, the justice values are in an important position. This can be seen in a statement of aja emban cindhe emban siladan. The suggestion of being fair is charged for everyone because basically each one is a leader for himself, his family, as well as the society or the government [5].

The meaning of justice contains universal moral values, which belong to the basic rights and needs of humans around the globe. The justice moral value becomes the goal of every nation in which it represents the interests of various groups. Thus, justice becomes an agreement among various elements of society who want a fair and prosperous state life. Likewise, the justice for Indonesian nation has been included in the fifth percept of Pancasila, namely the social justice for all Indonesians. This has been a pledge and an ideal for the entire Indonesian [6].

The abstract concept implementation into the legal formulations and its implementation in the society often cause problems, especially the problems related to justice. This happens because a law is a symbolic meaning which needs a further interpretation. Therefore, the justice problem, which is formulated by people, depends on the side they use to see it. As exemplified that the justice of the family sector will not be the same with the justice of criminal sector, state administration sector, etc. Thus, it can be said that the justice has a dimensional face [6].

Judges at all levels occupy a central position in a judicial process. They are expected to uphold the law and justice with that position. Issues needed to be resolved by the judges include the way an abstract justice containing certain values can be used as the guidance within its implementation. The work is to realize the justice idea and concept into the concrete forms so that they can be accepted by the people belongs to the judges' duty. The judges, through their decisions, are expected to have an ability to interpret the justice values within the problems they have to solve [6].

The justice that will be realized by the judges of the Administrative Court is Pancasilabased social justice. The term social justice is also contained in the Jakarta Charter of $22^{\text {nd }}$ of June 1945 and the Preamble of the 1945 Constitution. Soekarno in the BPUPKI session of $1^{\text {st }}$ of June 1945 used the term social justice and social welfare [7].

Justice as a goal is not a monopoly of a particular school of thought. It was even Adam Smith, who is considered as the founder of liberal economic thought and economic market, 
trying to realize the social justice and social welfare by saying no society can surely flourish and happy, of which by far the greater part of the number are poor and miserable. Jeremy Bentham said about the greatest happiness for the greatest number. Moreover, Henri de Saint Simon, a well-known France thinker, said from each according to his ability, to each according to his need [7].

The 1945 Constitution of the Republic of Indonesia requires Indonesia as a social state. The core of social state is the social justice consisting of social welfare. The founding leaders, who discussed the 1945 Constitution formulating the Constitution, also required the social justice. The desired concepts consisted of kinship, mutual helping, mutual cooperation and social justice. The realization of social justice requires at least two aspects, namely: First, it might provide them with a certain level of material goods. Second, it might promote a certain level of goodness of life for them [8].

The supervisory function of the Administrative Court in Pancasila-based legal system as the moral basis of Indonesian law should be able to realize the social justice, which creates a balance between the individual and public interests. The law carries expressive and instrumental functions. It is said carrying the expressive function, in which it express the way of life as well as cultural and justice values. Moreover, it also carries the instrumental function, in which it is as the means to create and maintain the order, stability, and predictability, the means to preserve the cultural values and to realize the justice, the means of education and community service, and the means of community renewal [7].

The Indonesian legal system transforms the basic values of Pancasila, namely the justice value in each judges' decision. The Administrative Court Decision has to be able to realize not merely the normative and procedural justice, but also the social justice. This emerges discourses on justice and legal certainty in the implementation of the Administrative Court's supervisory function. The justice cannot be held without a fair juridical order. This juridical order also belongs to social justice order, which guides the people toward a common good. The common good is a situation in which each individual can give and accept or sacrifice each other in order to realize justice [9].

The principles of conformity, balance, and concordance also contain the idea of a balance between the individual interest and public interest, which concern the public. Therefore, it is not only the individual protection which is highlighted. On the contrary, it does not let the public interest for becoming the reason to suppress and harm the individual interest.

This is what distinguishes the Indonesian Administrative Court with the Administrative Court in the developed countries, which adhere to individualism-liberalism principle and has a different philosophical, cultural, and social political background such as in France, the Netherlands, and Germany. However, the individualism principle within those countries is not implemented absolutely. This is seen from the jurisprudence development, from conseild'Etat, that there is a tendency to consider the public interest as the interest which should be protected.

\section{Objectives of the study}

The research raises the issues on what the justice meaning in administrative dispute resolutions is and what kind of social justice design will be realized by the judges of Administrative Courts. 


\section{Methodology}

The research is a doctrinal legal research that is a research which provides a systematic exposition of the rules governing a particular legal category; analysis the relationship between rules, explain areas of difficulty and perhaps, predicts future development [8]. It critically evaluates the rule of law, doctrine and concept as well as the legislation in accordance with their context.

\section{Discussion}

The Administrative Court functions to supervise the government. This is because the core or the nature of the state administrative law is dual, namely first: enabling the state administration to carry out its functions and second: protecting the citizens against the attitude of the administrative action itself. Besides the two Administrative Court's functions, the presence of the Administrative Court is also for maintaining the balance between the individual and the public interests. The Administrative Court is built on the basis of the state's philosophy of Pancasila, which maintain the balance, concordance, conformity, and harmony between the government and the people.

There are four elements of Pancasila Law State, namely: (a) the correlation conformity between the government and the people on the basis of the harmony principle, (b) the proportional functional correlation among the state's power, (c) the principle of resolving a dispute through a discussion and putting the courts as the final solution, and (d) a balance between the rights and obligations [2].

In the conformity principle, the balance and concordance also contain the idea of a balance between the individual interest and public interest, which concerns the public. Therefore, it is not merely highlighted the individual interest. On the contrary, it does not let the public interest to be a reason for suppressing and harming individual's rights within the society.

The Founding Fathers and the Framer of the Constitution, when discussing the basic concepts of the 1945 Constitution, agreed to reject all forms of capitalism, liberalism, and individualism. Sukarno did not want the western democracy but life-giving deliberation, which is able to bring about social welfare. Mohammad Hatta argued that political democracy alone could not carry out the equality and brotherhood. This did not mean that the 1945 Constitution required Marxism in achieving social justice. It was based on Mohammad Hatta's argument that there were three concepts underlying the social democracy in achieving the social justice. Those three concepts are (1) western socialism concept, which is attractive because it's goal is defending the humanity, (2) the Islamic teaching, which demands the divine truth and justice within the society as well as the brotherhood among the people as the God's creatures according to the loving nature of Allah (3) the knowledge that Indonesian society is based on collectivism [7].

Soediman Kartohadiprojo [11] said that social justice implies: First, the social justice is an abstract idea. Although he started his analysis by saying that each individual surely has four elements or has his life equipment, namely the body, the feeling, the ratio, and the harmony. He emphasized the importance of those four elements to be well maintained so that they will create peace, balance, and harmony. The ability in maintaining these four elements is interpreted as happiness. Thus, the social justice is a social welfare. The social welfare is a happiness. Second, if the keywords of the social justice are welfare and happiness, when those keywords are implemented in a law state context, the idea can be read as the idea of a welfare (law) state. Third, a legal revolution was interpreted by Soediman as a legal awareness change for living as an independent nation. Fourth, Soedirman's thought on social justice and legal revolution gave a warning to Soekarno's big ideas, so that thought adjustments are needed in the recent context. 
In the Indonesian context, the justice theory has to be in accordance with the truth of the Indonesian thought system. The Indonesian thought system and the justice should be in line with the nation's ideology, namely Pancasila, and the Indonesian legal basis, 1945 Constitution of the Republic of Indonesia. [10]. The meaning of social justice for the entire Indonesian is in line with the Preamble of the 1945 Constitution, which is in the fourth paragraph, as the incarnation of the Indonesian Proclamation text containing the objectives of the establishment of the Republic of Indonesia [12].

There is a principle similarity among John Rawls theories [12], such as they similarly respect the individual basic rights in its original position, without any discrimination, in order to realize the social justice through democratic principle or through the mutual agreement result. The social interests are above the individual interests. However, it does not mean that it eliminates the individual rights, as in the socialist communist system and utilitarianism concept which are based on the theory of theological ethics [12].

\section{Conclusion}

The Administrative Courts in developing countries carry out heavier duties than those in settled countries. It happens because they have to maintain the balance and harmony between the protection of the public interests and service with the protection of the individual interests. In other words, the development interests concerning many people and public interests cannot be inhibited by the individual interests. The individual rights cannot also be violated arbitrarily for the sake of development and public interests. There are two terms appearing as if face to face, namely the individual interests and the public interests. However, those two possibilities are not always not in line. The existence of the state and the government do not aim to eliminate one of the two interests, but they are more to find the balance between the two poles, without negating one another. In the Indonesian state system, the pendulum from the two poles lies at a point closer to the pole of public interests. This can be seen in the 1945 Constitution that collectivity, togetherness, and mutual cooperation take precedence over narrower interests. The cultural values among the society, which traditionally tend to give more emphasis on togetherness than individualism.

\section{References}

1. Y. J. Utama, Membangun Peradilan Tata Usaha Negara Yang Berwibawa (The Paper from Professor Inauguration of Diponegoro University, 2009)

2. S. F. Marbun, Peradilan Administrasi Negara dan Upaya Administratif Di Indonesia (F.H. UII Press, Yogyakarta, 2011)

3. Y. J. Utama, Upaya Perlindungan Hukum Bagi Masyarakat Yang Dilakukan Oleh Peradilan Tata Usaha Negara (This Paper is Served as Discussion Material in Discussion Forum, 1995)

4. M. Q. Shihab, Wawasan Al-Quran Tafsir Tematik Atas Pelbagai Persoalan Umat (Mizan, Bandung, 2013)

5. N. Kholidah, Konsep Keadilan dalam Serat Katildha karya Raden Ngabehi Ranggawarsita (Tesis, Institut Agama Islam Negeri Walisongo, 2014)

6. E. Warassih, Pemberdayaan Masyarakat Dalam MewujukanTujuan Hukum (Proses Penegakan Hukum dan Persoalan Keadilan) (in the Paper of Madya Professor Inauguration, 2011)

7. B. Manan, Peranan Hukum Dalam mewujudkan Cita-cita Keadilan Sosial Menurut UUD 1945 (Varia Peradilan-IKAHI 340, 2014) 
8. J. Asshiddiqie, Konstitusi Dan Hak Asasi Manusia, Bahan disampaikan pada Peringatan 10 Tahun KontraS, Jakarta (2008)

9. W. R. Tjandra, jmh Special Edition, Pp. 75-88 (2011)

10. P. M. Marzuki, Penelitian Hukum (Kencana Prenada Media Group, Jakarta, 2005)

11. S. Shidarta, Veritas 1, 1, Pp. 20-38 (2015)

12. F. Fadhilah, Kyberman 3, 1, Pp. 25-37 (2012) 